\title{
Mechanism of Power
}

\author{
Mohamad Haj Mohamad ${ }^{1}$ \\ ${ }^{1}$ English Department, Middle East University, Amman, Jordan \\ Correspondence: Mohamad Haj Mohamad, English Department, Middle East University, Amman, Jordan.
}

\author{
Received: January 22, 2018 Accepted: March 21, 2018 Online Published: May 14, 2018 \\ doi:10.5539/ells.v8n2p92 URL: https://doi.org/10.5539/ells.v8n2p92
}

\begin{abstract}
This paper attempts an examination of the concept of the mechanism of power in Suzanne Collins' trilogy The Hunger Games. The author conducts an analytical approach to the way power is practiced, the measure that helps establish a clandestine of power relations affecting people's life, mentality of thinking, politics and even economy.

The introduction delves to present a definition of power and its concept and how it gets activated and why. Power, according to Collins is the backbone and even the elixir of life upon which the very survival of the authoritarian state headed by President Snow depends. The paper goes on to explicate the need for keeping power in place to secure the government's grip on power. Mechanism of power as shown in the novel works on so many levels. Divide and rule marks the first and most necessary and effective means as a divisive policy aiming at preventing any potential unity among people who might employ this unity to rise up against the totalitarian government. Media and sport and economic factors are used effectively to ensure government's control on man's mind, body and soul and intimidate them whenever needed. Collins presents power and its mechanism as the sole relation between people and government in the novel. Absence of democratic rule in Panem, or, American states, leaves power as the only means to describe the social bond between man and state, a bond that is unilaterally respected and practiced.
\end{abstract}

Keywords: power, hunger, totalitarianism, death, revolution, media

\section{Introduction}

Michael Foucault, the French philosopher, believes that the image of modern society in some places is a highly institutionalized one (Foucault, 1977, p. 43) conditioned and tempered by indoctrinating it into culture, education, economy and psychological measure. Society, thus, could be rendered to a mass concentration of people who need and should and have no other choice but to follow dictates set by authority, which through its net of measure and laws affects and restricts all aspects of life and on top of that creates a platform for a relation between man and laws or governor. As such, relation between man and power is so simple, yet it is a highly complicated one where it implies surrender or going against it with all what such a move may entail. Pursuing power regardless of its nature functions to help give strength and maintain and sustain man's desire for safety and dominance, an approach men of letters felt indispensible to weave into the tissue of their works as a highly esteemed value that can be classified into two categories: constructive or destructive as is the case in Suzanne Collins' trilogy The Hunger Games. The novel explicates the mechanism of the relations of power where the social the political and the economic ones overlap to show a clandestine networks destined to take hold or maintain grip on authority as is the case with the tyrannical regime in the capital where power is badly sought after and, moreover, it borders on the issue of existence itself where any change of power is definitely conducive to change of being. This paper attempts to cast a light on the concept of power as seen in Suzanne Collins' The Hunger Games where man has become the victim of this merciless game infiltrating his mind body and even dreams.

\section{Aspects of Science Fiction in Post Modern Culture}

Post modern culture has given birth to science fiction, a genre that reads into the seed of the future, mostly, in a dystopian fashion. This type of art made a remarkable access to readers by appealing to youngsters and adults who find in such a literature the attraction of "pleasure and challenge". (The pen, 2015, p. 39) Setting and plot function to present a futuristic milieu and a jump into what might seem as forthcoming events that might seem potentially surrealistic in nature yet they still have their roots at present. In other words, science fiction could be 
an exploration of man's dormant psychology that travels in time for more of self discovery and expectation creating feelings of fear or longing. The woven futuristic vision is set to race against or go ahead of the rapid pace of technological progress that affects social development be it economic, cultural political or otherwise. Suzanne Collins The Hunger Games, is one of this genre science fiction that attempt a reading into the future showing a clandestine of dilemmas created and nurtured by authoritarian approach to the social bond between man and government seen as designed to suit totalitarianism.

The Hunger Games (2008), written by Suzanne Collins, is a dystopian/science fiction trilogy that has been marked as a best-seller in America. Some critics claimed that a best-seller literature has no food for thought. However, there is no logical reason for ostracizing best-seller books from the literature category simply because reading dystopian novels has increased recently, not only for their captivating plots and their sophisticated technologies, but also for the implied call dystopian novels make for a change in societies that need to explore the awaited future right in the present.

\subsection{Book Summary}

The novel could be sketched in the equation of dominance and obedience, fear and submission involving people and government. The setting describes future events set in Panem, a virtual and a non- existent country, that once people called it North America and now is living under the dictatorship of President Coriolanus Snow where the relation between people and government is highly strained due to the oppressive nature of the regime. Panem is a place that:

rose up out of the ashes of a place that was once called North America...a shining Capitol ringed by thirteen districts, which brought peace and prosperity to its citizens. (The Hunger Games, p. 20)

The name Panem refers to the "Panem et Circenses" that translates into "Bread and Circuses" that was used in Satires by the Roman poet, Juvenal. This term goes back to the Roman Empire which implicitly sanctioned it as political ploy mastered by politicians to keep people satisfied and timid with the government policies and political system. "bread" food and "circuses" entertainment. (The pen, p. 16) are set to buy people's consent and even silence. A policy and a scheme that in reality meant pacification of people in return for bread and food.

\subsection{Panem Government and Relation with Its People}

Panem is divided into thirteen districts and each gives its share of wealth and product to the the government which resides over a highly institutionalized and centralized apparatus, isolating itself from people and maintaining a solid grip on power. The district where the government seat is located retains most if not all prerogatives facilitated by its acquisition of wealth and undisputed power. The Rest of the states languish in abjure poverty and destitution coupled with a state of fear exercised by the country's oppressive machine.

The typology of power found in Panem "embraces force, authority and manipulation" (Lucks, 1974, p. 21)

The Capitol is described as a large city located in the Rocky Mountains centering the 13 districts, the number of districts of which country consists. In Panem's capitol people lead a life of affluence giving them an extravagant style of daily life. They spoil themselves for choices in a life of plenty that offers exotic range of food and fashionable dress. Whiskers on faces and applying striking colors to bodies distinguish capitol residences from and juxtapose them against fellow citizens in other districts whose main objective is survival let alone the luxury of life. Therefore, they feel happy and satisfied with a meager ration of food and basic diet. Sharp difference between the capital and the rest of the districts work out in favor of the capitol that drains all resources, industrial and agriculture and likewise by exerting the power that render the rest of the states orbiting in its sphere of influence. The division of the country into thirteen states serves to the transfer to and concentrate wealth in the capitol, making its political power yet stronger and more effective. Power relations therefore can be described in simple sentence; ruling and oppression. So the overpowering political influence of the capitol facilitates its acquisition of further of other spheres of power like economy and media. Next to manipulating people's income and production, media employs its web of clandestine procurement networks to brain wash people if possible and intimidate them by exerting on them maximum influence of fear and persuasion to take things for their face values. To implement this policy the government employs a strategy of mass intimidation, that is holding of annual games, apparently to entertain people but in reality the objective is entirely different. President Snow's totalitarian government is substantially concerned with philosophy of power to consolidate its grip on the developments of events. Annual games give the best platforms to galvanize and polarize people's attention around the results that give clear messages that are in reality free from being fair simply because games lack free competition. Mechanism of power, as such, presents a version of reality as seen by the government which believes in the policy of forced discipline. That is why hunger games are meant to serve politics. 
Hunger game is in reality far from being a true sport. As the name suggests the game is a competition in hunger. Games, are supposed to solidify social fabric for being human and social interaction. However, hunger games backfire pain and fear especially when media, the mighty governmental weapon, gets this message across to all people. Hunger games have been observed for a long time. The country's seventy fourth annual hunger game is a televised one where districts compete in a hunger game played off to select the victor in hunger, an event reminiscent of ancient tribal rites where sacrifice of human blood was needed to stimulate a bonanza harvest. In the games each district is represented by a boy and a girl who should go on hunger game. They should compete in a fierce and merciless game. The implied message the games give is far from fairness and friendly sport competition. The country is run by an iron fist, so to speak, and the games by the help of the media are destined to extract obedience from people and render them hypnotized so that they would not entertain thinking of any uprising against the regime.

Catching Fire (2009) stresses the responsibility that comes with power. The novel describes how the people of Panem were imprisoned in a harsh winter of dictatorship and cruelty. Yet, citizens are getting stronger now, they long for creating their own democratic era, "spring would be a good time for an uprising, I think. Everyone feels less vulnerable once winter passes." (Catching Fire, p. 167) Katniss, the heroine was the spark of the rebellion; she inspired people around the districts to stand up for themselves and most importantly, to demand their rights as human beings.

\section{Distribution of Power in the Republic of Panem}

In the republic where events take place power does not look fairly maintained. Balance of power works exclusively in favor of the capitol which enjoys all prerogatives as a result of power concentration in the hands of the elite, the clique in the case of Panem, while the rest of the districts tail behind in all aspects of life. As a result of that there has become a huge gap between life and people in the capitol and their counterparts in districts where People are forced to send their children to the Hunger Games where the winner would enjoy the fame of getting hungry in a competition while their counterparts in the capitol stay with their parents watching with excitement their districts peers getting starved and slayed. People are supposed to sanction and enjoy this brutal game, while the luxurious life people of the Capitol lead, blinds them from recognizing the peril brewing in the districts. Therefore, the game of power works for their benefit. It is their protection and entertainment. They have everything, food, money, and there is no need for them to mount any rebellion against the Capitol:

There is no danger of an uprising here among the privileged, among those whose names are never placed in the reaping balls, whose children never die for the supposed crimes committed generations ago. (Catching Fire, p. 73)

The government looks barricading itself behind this supportive human shield. Concentration of Power in one side makes unfavorable images look normal. Striking images about life in the capitol force comparison with other districts. Katniss, the heroine, loathed how naive and shallow the people of the Capitol are, how extravagantly they dress, eat and live. Their life could be summed up with one single statement; live to eat not eat to live as is the case in the rest of the districts. The comparison is yet more shocking. Katniss recalls how starvation has become the shadow of every citizen in District 12, and she could not do anything to help those in need. Whereas, for the Capitol's people, eating is an activity of pleasure, not a necessity: The comparison tells that

often in the old days, there was nothing to give and the child was past saving, anyway. And here in the Capitol they're vomiting for the pleasure of filling their bellies again and again. Not from some illness of body or mind, not from spoiled food. It's what everyone does at a party... Part of the fun. (Catching Fire, p. 80)

For the undisputed master there is the capitol looks enslaving the rest and this sort of maximum power is exerted to abort any future dissent. That is why the capitol drives deep social and economic and even psychological wedges among people by creating dystopian atmosphere in the districts, and sustaining a utopian one for the elite citizens of the capitol. Furthermore, the Capitol monopolizes most resources and allocates them only to the privileged to buy their loyalty and silence. In order to hammer home this objective the government subjects the surrounding environment of the districts to merciless exploitation including material and labor and above all "ripping-off their freedom of speech, and their freedom to live as humans. (Parker, 2008, p. 288) Denial of personal freedom is nothing more than an implementation of an abortive political scheme that keeps every person under close surveillance. 


\subsection{The Political Strategies of the Capitol}

The Political strategies of the Capitol commissioned political technologies or what Foucault calls disciplinary structures. In order to rein in its "citizens watch towers were set up" called the Panoptic, designed by Jeremy Bentham (1748-1832), )which is a tower with prison cells that circulate around a guard tower so that prisoners will be watched by the guard (Parker, 2008, p. 272). The Panopticon works as a way of individual control, in which it creates labeling and binary division in Panem (Capitol/District). And according to Foucault's description of the Panopticon, districts are being treated as abnormal while the Capitol is labeled as normal, through which the normal is monitoring, supervising and correcting these abnormalities and bringing them into line with the general policy of the state. The policy is meant to infiltrate the very tissues of the brains of people so that behavior and actions can be controlled. More than that the state manages to hypnotize them into blind submission. (Focault, 1978, p. 199) As such, Panem' residents would accept any policy advocated by the government.

As a measure to further strengthen its grip on power, districts are manned by a human power, falsely, called Peacekeepers, who are in reality far from being powers for peace. In addition to that, latest technological devices have been set up to keep an eye on people. In addition to electric fences that surround each district, cameras are installed everywhere even in the woods. Everything is being under close camera surveillance recording and counting every thing. So on Katniss's and Peeta's victory tour through the districts following the end of hunger games, Katniss notices how massive efforts and surveillance were made by the Capitol to maintain obedience in District 11. A thirty- five feet electric fence, strategically placed towers, heavily armed guards among the fields are round the clock. "Then I see the watchtowers, placed evenly apart, manned with armed guards, so out of place among the fields of wildflowers around them. (Catching Fire, p. 55)

Next to that, the Capitol is forming a type of coercion upon the body of citizens monitoring and dominating their behavior and action creating what some philosophers defined as docile or tamed bodies. People, in this case, unquestionably give in to government on one hand and, equally important, they develop government phobia, a fear that leaves them in square one unable to object nor even have the luxury of time to resist. In Discipline and Punish: The Birth of the Prison, 1977, Foucault explains the strategy of coercion upon the body of citizens:

a policy of coercions that act upon the body, a calculated manipulation of its elements, its gestures, its behavior...If economic exploitation separates the force and the product of labor, let us say that disciplinary coercion establishes in the body the constricting link between an increased aptitude and an increased domination. (Foucault, 1977, p. 138)

Denying man selfhood renders him a machine - like being. The Capitol, in maximizes exploitation of physical power by depleting it in harsh working schedule. So "Men, women, and children wearing straw hats to keep off the sun...Small communities of shacks ...but they're all deserted. Every hand must be needed for the harvest." (Catching Fire, p. 55)

\subsection{Mechanism of Power}

Power, it has been argued, works to draw a line of demarcation between the influential and the influenced. The type of power the Capitol has is a Coercive power depending on sheer and pure authority on the receiver who is under constant threat of "punishment if he does not act/behave the way he is supposed to (French \& Raven, p. 263). Practicing this sort of power, economically speaking, renders man a productive machine where the capitol forces people to produce and make products and send them to the Capitol under the constant threat of death for any one who flouts government's laws. People could even meet their own death in case of any sign of mute rebellion. In this case they are liable to lose not only their freedom but their identities as well. According to Sarah Collinson (2003), since the identity and wealth of the districts' people are being violated they are vulnerable and powerless; therefore the Capitol dominates districts and violently punishes them taking away their products and identities:

Power and powerlessness determine the distribution of access to food and other key commodities and assets among and within different groups. Those who lack power cannot safeguard their basic political, economic and social rights, and may not be able to protect themselves from violence. (p. 10)

Unequal distribution of power is conducive to lack of unbalanced resources availability among people. This case is manifested in the capitol's policy that exhausts districts' resources and denies them any true sharing of their products. When Katniss met Rue; tribute from District 11 in the games, Katniss thought that in District 11 they have more food because District 11 is an agricultural district. However, Rue explained that they are not allowed to eat any of the crops. "Rue's eyes widen. "Oh, no, we're not allowed to eat the crops." "They arrest you or something?" I ask. "They whip you and make everyone else watch," says Rue" (The Hunger Games, p. 237). 
Keeping power exercised on people is not only limited to its physical aspect. Images facing people everywhere reminding them of the eyes watching them is a true norm of power and an effective means of capturing man from within i.e., psychologically controlling and infiltrating man's being and depriving him from his basic psychological balance, thus separating people and even dividing man from himself. Splitting man apart, psychologically speaking, renders man a shaky being barley able to stand, let alone to think and mount a revolution. This policy is applied nation wide on personal and social levels. Divide and rule can be seen as the most effective way to break the social fabric in any society. The Capitol refers to isolation as a strategy for keeping the people of the districts ignorant about each other. Keeping people apart is coupled by strong media indoctrinating people into accepting the official version of any given report. Therefore, they will not form an alliance against the government, and the Capitol can subjugate the districts with ease. Katniss has mentioned that traveling between districts is prohibited, and their knowledge about other districts is only limited to what they have been taught in school and what has been broadcasted during the games. Moreover, the Capitol encourages mistrust among citizens effectively denying them any attempt to sympathize with one another and hence sympathy during the games is considered a forbidden sin between tributes. The Capitol is trying to prevent any act of kindness between people, aiming to strip them off from their humanity. Consequently, the Capitol's goal is to create a huge division between districts; and even divisions within the districts themselves, following the strategy of divide and rule.

\subsection{Brutal Power and Its Nature}

To decide who lives and who dies is a prerogative reserved to sovereign power in totalitarian regime. In The History of Sexuality (1978), Foucault describes how the powerful person uses the life and death privilege as a condition to defend himself and his so called sovereign power. President Snow of Panem referred to death as a solution to exterminate the rebels during the first rebellion, a final measure that was "a method the sovereign deployed to express his or her power" (Foucault, 1979, p. 17) Also, in organizing in the Hunger Games he uses death as a solution to any emergency and as a reminder of the previous revolution where, children got killed so that their death would give him the victory to thrive and continue his ruthless rule. Snow wants to show Panem that he has the "right of seizure: of things, time, bodies, and ultimately life itself; it culminated in the privilege to seize hold of life in order to suppress it." The Hunger Games (pp. 135-136).

Therefore, killing as a victory to government agents is, in short, a license to kill and hence more ways of killing could be possible. President Snow discussed with Katniss her poisonous berries trick, another fatal web. He tells her that he killed Seneca Crane; the previous Game maker whose actions were, falsely, translated as an act of rebellion. He goes on to tell her that he could have even killed her and Peeta. Systematic killing as practiced by President is a naked application of brutal power. He gives her a bone-chilling message. "If the Head Game maker, Seneca Crane, had had any brains, he'd have blown you to dust right then. But he had an unfortunate sentimental streak. So here you are. Can you guess where he is?" (Catching Fire, p. 20)

To further consolidate grip on power a further measure is practiced. In Discipline and Punish the Birth of the Prison (1979), Foucault discussed how prisoners were being tortured by constant surveillance as a disciplinary punishment. Snow, in reality, is the jailor and people of Panem are the prisoners. Restrictions imposed on communication among people leaves deep psychological and cultural scars. Other physical measures are applied to second psychological counterparts. Punishment awaits any one who flouts the law. Public lashing, execution of the guilty are sometimes extended to include family members. Gale, a citizen, caught with a turkey, is publically whipped by Commander Thread, who is the new head peacekeeper in District 12 . This is to deter people from hunting which is made illegal to keep people hungry and needy. Hunting is illegal in District 12, "Hunting in the woods surrounding District 12 violates at least a dozen laws ...punishable by death." (Catching Fire, p. 9) So the mechanism of power is extendable to wheel man into an ever begging person for his/her basic daily needs. However, such a punishment and exercise of power is devilishly pushed to unprecedented frontier. The Capitol considers and treats prisoners as traitors. Prohibiting talking marks one of the despicable punishments for prisoners who have to zip their mouths to bar them from voicing their horrible experiences especially when they are forced into sewer systems as workers. Banning sympathy is manifested in the case of Gale who when was being whipped Darius, a Peacekeeper in district 12 gets disciplined for interfering with Threads punishment of Gale. Later on, Katniss discovered that the Capitol has turned Daruis into an Avox, a prisoner and positioned him as her help in her Capitol apartment. This measure taken is a message to Katniss and of family warning them of yet worse penalty in case they defy the government or even show any sympathy with others

No, Darius shouldn't be glad he knew me. If I had been there to stop Thread, he wouldn't have stepped forward to save Gale. Wouldn't be an Avox. And more specifically, wouldn't be my Avox, because President Snow has so 
obviously had him placed here for my benefit. (Catching Fire, p. 218)

Another form brutal application of force and denial of sympathy between people lies in nature of games the government holds.

\section{The Game of Death, Development of Hunger Games}

The games start with Katniss Everdeen, a girl from district twelve volunteered to go on behalf of her sister and competes against Peeta Mellark, a male tribute. The game is nothing but a death completion where one should survive this open game. Katniss has unexpectedly and untraditionally managed to save the life of the competitor who should be finished off. But she showed humanitarian approach toward her competitor, a move incompatible with the needed outcome, that is death to one of the competitors. On the return to district 12 crowned as victors of the 74th hunger games, President Snow has warned Katniss of her attempt to eat some poisonous berries to save Peeta and for that he would not allow her to be the symbol of a revolution. For President Snow what she did is an act of defiance except in one case. She has to convince him and Panem that what she did was only an act of deep love for Peeta and not an act of a rebellion against the Capitol. Therefore, President Snow has threatened Katniss to kill her family and her best friend Gale if she did not fully convince him that she is madly in love with Peeta. Katniss and Peeta's Victory Tour through the districts, carries a double message. Seeing the poor and repressed backfires psychological fear on one hand and reminds people even victory will not alleviate their suffering. In district 11 for instance, which is Rue's and Thresh's district, she noticed the massive surveillance the Capitol has built to maintain obedience. To make sure that no one is eating the crops,

In the midst of this deadly game of power Peeta is on the receiving end. She has to convince President Snow that is why she went for proposal to Katniss in in public. President Snow implemented this occasion to enhance his image. He holds a lavish party at his mansion to celebrate this event. However, his looks tell of his dissatisfaction and Katniss needs to go further. People of the Capitol praised her devotion for Peeta; they liked how she was desperately trying to save him using the berries. She loathed how naive and shallow the people of the Capitol are, how extravagantly they dress, eat and live. At the party, Katniss and Peeta got to meet Plutarch Heavensbee the new Head Game Maker, the successor of Seneca Crane, who was killed by President Snow. She noticed that Plutarch Heavensbee has a Mockingjay watch, but unlike the people of the Capitol he was not wearing it as a fashion trend, but he was wearing it as a symbol of resistance, a message giving an implied warning of a potential rebellion. This potentiality came into being when Katniss who dinned at Mayor's office during her Victory tour saw on the mayor's office television a news report about an uprising in District 8, news confirmed when Katniss met Bonnie and Twill who have escaped the rebellious district. The two escapees, Bonnie and Twill are heading for district 13; the main center for nuclear weaponry, which was once destroyed by the first rebellion, is now functioning and accepting refugees. This uprising is the expected nightmarish scenario for president Snow was afraid of. However, absorbing the shock and then going on the counteroffensive is a measure president Snow is a master at it. Shortly thereafter, the news of the Quarter Quell was announced by President Snow: "as a reminder to the rebels that even the strongest among them cannot overcome the power of the Capitol, the male and female tributes will be reaped from their existing pool of victors." (Catching Fire, p. 172) Katniss and Peeta were going back to the arena, a place for further practice of power.

In the arena, Katniss and Peeta teamed up with Finnick, Beetee, Wiress and Johanna. The tributes have discovered that the arena was designed as a clock, and at each hour there is a specific torture. The game ended after Katniss shot the dome of the force field with her arrow blowing up the arena. After that, Katniss wakes up in a hovercraft heading for District 13 after when she learned from Gale that District 12 was blown up and he successfully rescued her mother and sister from there. Hunger games are reminiscent of Roman history and fights to death in arenas, even, sometimes, against predators where chances of survival are very slim. These games which are annually held have two objectives: implicit and explicit. Sport is supposed to be a fair and friendly competition. However, for president snow it is set to help stabilize his regime. These games distract people's attention from their genuine suffering, deplete power and intimidate them making them see for themselves hunger and blood rites. This annual barbaric event involves all districts that have survived the war. They have no choice but to sacrifice two tributes; a boy and a girl between the ages of twelve and eighteen, in a fight to death in a deadly arena. This event means a fight to death live on T.V. Most graphic is that this deadly duel is televised to all including families and loved ones. The government wants to keep the memory of the failed uprising alive and give another undisputed proof of its undisputed power.

Our yearly reminder that the Dark Days must never be repeated, it gave us the Hunger Games.... this is the Capitol's way of reminding us how totally we are at their mercy. (The Hunger Games, p. 21)

In order to curb any potential intellectual dissent, Capitol employs media as a weapon of mass control. 
Monopolizing and politicizing media serve as a platform for governmental propaganda where truth and reality are the first victims. Politicized media is nothing more than a petty tool for mass manipulation. Controlled media could skillfully alternate facts in a way that serves the Capitol's agenda. According to Samira Sasani and Marjan Darayee discussion of the society of the spectacle, the ruling clique employs visions and images to blur reality. So media, entertainments and games attract people's attention. This too much attraction leads people not to see the reality of the society and the dictatorship of the capital imposing inequality and enmity on people. (Catching Fire, p. 32)

Hunger Games could have the effects of sedatives and drugs at the same time. People look hypnotized and ready to accept any doses of false information given to them especially when forcibly entertained by what looks like a huge reality show to divert attention from dictatorial practices. When District 8 started the uprising, the Capitol stopped the spread of the rumor of District's 8 uprising, by orchestrating an engagement for Katniss and Peeta and broadcasting it on the day of the uprising, as a massive cover up to, figuratively speaking, blindfold people from what is really going on.

The night of my engagement, the night Peeta fell to his knees and proclaimed his undying love for me in front of the cameras in the Capitol, was the night the uprising began. It was an ideal cover. (Catching Fire, p. 144)

The Capitol's appetite for orchestrated violence is not fulfilled with annual games only. Every 25 years of the revolution previous games victors of the annual have to fight each other in the Quarter Quell; which is another manifestation of oppressive power. It is a fierce play off competition in a more dangerous arena and this works to indirectly convince people that nothing could be done and no one stands any chance for freedom and people's deplorable conditions have no chances of nay improvement. The message is so simple and clear. They can not free themselves. They will remain enslaved by the Capitol; and any glimpse of hope will be obliterated immediately and so is every attempt to rebel. It shall be put down mercilessly. In fact there is no hope. And now twenty-three of us will be killed to show how even that hope was an illusion. (Catching Fire, p. 175)

By Possessing resources and monopolizing them the government of Panem, seizes the organizational advantages in power relation. People's lives, bodies, environment, and tools of punishment have all been engendered to serve the mechanism of power the government plays. And, according to Mann's organizational outflanking principle (1986): "who possess the organizational advantage will always succeed in overcoming those who lack organizational resources." And hence the government maintains a sharp edge over any development.

Districts' surrender to the Capitol refers to the districts' knowledge deficiency, and the lack of knowledge could be the result of the following reasons according to Mann's concept. They are Ignorance, isolation and division. Districts' ignorance; about the Capitol's weaknesses bars needed information for any potential uprising. Isolation, keeps districts apart and ignorant about each other. The government sever communication lines between districts, ban travel between them and limit it to transferring supplies and this helps the government employ its divisive policy to push further divisions among districts. Districts, as a result, can not have the sufficient knowledge or even the organizational sources to resist. Hence government's mechanism of power helps establish an atmosphere of terror and deterrence. People are automatically wheeled into this atmosphere of fear. They can never entertain a rebellion which for sure they know it's very high and unaffordable cost of blood and tears and failure.

\section{Conclusion}

The unholy triangle of power, so to speak, money, media and security apparatus virtually imprison man within the boundaries of need and fear. Man virtually must have his voice muted and his ears trained to listen to the government's propaganda and his eyes are trained to watch its TV. Any attempt to violate this wicked web of power is doomed to failure if not to a bloody end. The Hunger Game is self explanatory where each party, government and person is hungry. Hunger for power or the lust for power makes it a very brutal game. The government's hunger for power traps president and its clique within a never ending game of power or in a hectic pursuit after power, else they would gradually lose grip on developments of events. Any turn of the tide of power is certainly fatal as is the case with any move to turn the table against the oppressor. People, on the other hand, are not less hungry for power than the government simply because they are ion they are on the receiving end. They, in short, want to feel power and its prerogatives. However, and given the government's uncompromising mood, their hunger may not be easily satisfied. People's hunger, in this case, is for the basic items and rights they are forced to relinquish. They are deprived from liberty, stable life and above all they are forcibly leading a life close to hunger and servitude. So "the state implements its discipline in a well organized routine which prescribes and shapes the thoughts and actions of every citizen in dystopian society. (Gerhard, 2012, p. 49) Power, in this context, is not totally negative; on the contrary, it could be seen as a convincing method to 
maintain discipline among people who without its effect would stick to their version of power or reality of power, a one-sided view that may not be the only real or even the constructive one. Even democracy at its best needs it "democratic" power to help the continuing process of democratization.

\section{References}

A Study of Dystopia as a Literary Genre. (2017). Retrieved from http://dystopiainstudy.weebly.com/

Bachrach, P., \& Morton, S. B. (1962). Two Faces of Power. American Political Science Review, 56, 947-952. https://doi.org/10.2307/1952796

Bălan, S. (n. d). M. Foucalut's View on Power Relations. Retrieved from http://cogito.ucdc.ro/nr_2v2/M.\%20FOUCAULT'S\%20VIEW\%20ON\%20POWER\%20RELATIONS.pdf

Blokker, J. J. A. M. (2014). Identity Formation in the Dystopias of the Hunger Games and Divergent (MA Thesis, University of Leiden). Retrieved from https://openaccess.leidenuniv.nl/bitstream/handle/1887/28594/Identity\%20Formation\%20in\%20the\%20Dys topias\%20of\%20The\%20Hunger\%20Games\%20and\%20Divergent\%20by\%20JJAM\%20Blokker_1447297. pdf? sequence $=1$

Bitoun, R. (2014). The Political Message of the Hunger Games. The Artifice. Retrieved from https://the-artifice.com/the-hunger-games-political-message/

Burnett, B. (2012). The Politics of the Hunger Games. HuffPost. Retrieved from http://www.huffingtonpost.com/bob-burnett/the-hunger-games-politics_b_1390945.html

Clegg, S. (1989). Framworks of Power. Thousand Oaks, California: SAGE Publications. https://doi.org/10.4135/9781446279267

Clegg, S., Courpasson, D., \& Nelson, P. (2006). Power and Organizations. London, Thousand Oaks, New Delhi: SAGE Publications.

Collins, S. (2008). The Hunger Games. New York, NY: Scholastic.

Collins, S. (2009). Catching Fire. New Yo.rk, NY: Scholastic.

Collins, S. (2010). Mockingjay. New York, NY: Scholastic.

Cook, S. (2001). Marxist Perspective of Power. Retrieved from https://revisesociology.wordpress.com/2011/11/29/6-marxist-perspective-of-power/

Cusey, R. (2011). The Hunger Games a blue-state Harry Potter. The Daily Caller. Retrieved from http://dailycaller.com/2011/08/29/the-hunger-games-is-a-blue-state-harry-potter/

Defining "Science Fiction": What is science fiction... and why study it? (n. d.). Retrieved from http://www.sfcenter.ku.edu/SF-Defined.htm

Dominus, S. (2011). Suzanne Collins's War Stories for Kids. The New York Times Magazine. Retrieved from http://www.nytimes.com/2011/04/10/magazine/mag-10collins-t.html

ESDAW. (n. d). Bread and circuses. Retrieved from http://www.esdaw.eu/bread-and-circuses.html

Finnsson, G. (2016). The Unexpected Popularity of Dystopian Literature: From Orwell's Nineteen Eighty-Four and Atwood's The Handmaid's Tale to Suzanne Collins' The Hunger Games Trilogy (BA Thesis, University of Iceland, Iceland). Retrieved from https://skemman.is/

Foucault, M. (1977). Discipline and Punish: The Birth of the Prison. NY: Vintage.

Foucault, M. (1978). The History of Sexuality, translated by Robert Hurley (Vol. I, p. 36). New York: Pantheon.

Foucault, M. (1980). Power/knowledge. Selected Interviews \& Other Writings, 1972-1977. In C. Gordon (Ed.). NY: Pantheon Books.

Foucault, M. (1982). The Subject and Power. Critical Inquiry, 8(4), 777-795. https://doi.org/10.1086/448181

Gerhard, J. (2012). Control and Resistance in the Dystopian Novel: A comparative Analysis (MA Thesis, California State University, Chico). from http://csuchicodspace.calstate.edu/bitstream/handle/10211.4/434/4\%2018\%202012\%20Julia\%20Gerhard.pd f? sequence $=1$

Giddens, A. (1984). The Constitution of Society: Outline of the Theory of Structuration. LA: University of California Press. 
Gventa, J. (1980). Power and Powerlessness: Quiescence and Rebellion in an Appalachian Valley. Chicago: University of Illinois Press.

Gaventa, J. (2003). Power after Lukes: An overview of theories of power since Lukes and their application to development.

Retrieved

from https://www.powercube.net/wpcontent/uploads/2009/11/power_after_lukes.pdf

Hamre, K. (2013). Suzanne Collins'Hunger Games Trilogy and Social Criticism (MA Thesis, University of Oslo, Norway). Retrieved from https://www.duo.uio.no/bitstream/handle/10852/37037/H.Hamre-MASTER.pdf

Henthorne, T. (2012). Approaching the Hunger Games Trilogy: A Literary and Cultural Analysis. North Carolina and London: McFarland \& Company, Inc.

Jessop, B. (2014). Marxist Approaches to Power. Retrieved from https://bobjessop.org/2014/03/27/marxist-approaches-to-power/

Lukes, S. (1974). Power: A Radical View. New York: Macmillan. https://doi.org/10.1007/978-1-349-02248-9

Mann, M. (1986). The Source of Social Power. NY: Cambridge University Press. https://doi.org/10.1017/CBO9780511570896

Mythphile. (2010). The Cornucopia (Horn of Plenty) in Greek Myth. Retrieved from http://www.mythphile.com/2010/11

McCall, D. (2015). Panem Ministry of Propaganda Maps of Panem. Retrieved from http:/www.panempropaganda.com/panem-maps/

New Dictionary of the History of Ideas. (2005). Dystopia. The Gale Group. Retrieved from http://www.encyclopedia.com/literature-and-arts/literature-english/english-literature-20th-cent-present/dyst opia

Nyman, R. (n. d). The Hunger Games as a Dystopian Fiction. NU Writing. Retrieved from http://www.northeastern.edu/nuwriting/the-hunger-games-as-dystopian-fiction/

N. W. Sociology. (2014). Gramsci and Hegemony. Retrieved from https://www.slideshare.net/NWsociology/gramsci-and-hegemony-32703423

Odlöw, E. (2016). What's in a Name? An Interdisciplinary Study of Allusive Character Names and Implied Meaning in the Hunger Games (BA Thesis, University of Gothenburg, Gothenburg-Sweden). Retrieved from https:/gupea.ub.gu.se/bitstream/2077/38564/1/gupea 207738564 1.pdf

Pavlová, L. (2016). Dystopian Elements in the Hunger Games Trilogy (BA Thesis, Masaryk University, Czech Republic). Retrieved from https://is.muni.cz/th/428622/ff_b/Bachelor_s_Thesis.pdf

Parker, R. (2008). How to interpret literature: critical theory for literary and cultural studies. NY: Oxford University Press.

Sadan, E. (1997). Empowerment and Community Planning. Translated by R. Flantz.

Sar, S., \& Sri Minda, M. (2012). Political Dystopia in Suzanne Collin's The Hunger Games. Retrieved from http://download.portalgaruda.org/article.php?article=126862\&val=3894\&title

Sasani, S., \& Marjan, D. (2015). Suzanne Collins' Hunger Games and the Society of the Spectacle. International $\begin{array}{lllll}\text { Letters of Social } & \text { Humanistic }\end{array}$ https://doi.org/10.18052/www.scipress.com/ILSHS.48.31

Scholes, J., \& Jon, O. (2013). Understanding the Appeal of Dystopian Young Adult Fiction. The Allan Review, 40(2). https://doi.org/10.21061/alan.v40i2.a.2

Scott, J. C. (1990). Domination and the Arts of Resistance: Hidden Transcripts. New Haven and London: Yale University Press

Sterling, B (2016). Science Fiction. Retrieved from https://www.britannica.com/art/science-fiction

Thepen, R. (2015). Young Adult Dystopian Literature on Fire: The Importance of the Hunger Games Trilogy to Critical Thinking and Social Justice (MA Thesis, University of Groningen, Groningen). Retrieved from http://arts.studenttheses.ub.rug.nl/16714/1/MA-2057816-R.M.S._Thepen.pdf

The Editors of Encyclopædia Britannica. (2002). Resistance. Retrieved from https://www.britannica.com/event/resistance-European-history

The Hunger Games Wiki. (n. d). Retrieved from http://thehungergames.wikia.com/wiki/Main_Page 
Vinthagen, S. (2007). Understanding Resistance: Exploring Definitions, Perspectives, Forms and Implications. Gothenburg University,
http://www.resistancestudies.org/files/VinthagenResistance.pdf

Vinthagen, S., \& Johansson, A. (2013). "Everyday Resistance": Exploration of a Concept and its Theories. Resistance Studies Magazine, V(1). University West: Sweden. Retrieved from http://www.resistancestudies.org

\section{Copyrights}

Copyright for this article is retained by the author(s), with first publication rights granted to the journal.

This is an open-access article distributed under the terms and conditions of the Creative Commons Attribution license (http://creativecommons.org/licenses/by/4.0/). 